Marwah: Jurnal Perempuan, Agama dan Jender

(p-ISSN: 1412-6095 | e-Issn: 2407-1587

Vol. 18, No. 1, 2019, Hal. 67-86

\title{
SUBJECTIVE WELL BEING DALAM PERSPEKTIF ISTRI BERJAUHAN DENGAN SUAMI
}

\author{
Sri Suwartini, Casmini \\ Universitas Islam Negeri Sunan Kalijaga, Yogyakarta, Indonesia \\ riri.srisuwartini@gmail.com,casmini@uin-suka.ac.id
}

\begin{abstract}
This study discusses a long-distance marriage relationship between a man or woman who has two careers. Each has a desire to retain marriage but on the other hand chooses to maintain a career, so that the couple must have a strong commitment. This study was conducted on five married couples who had long distance relationships. These five couples were chosen because of their ability to keep their households in harmony even in long distance conditions. A psychological approach is applied to examine it, particuarly with the theory of subjective well-being. Happiness in the context of subjective well-being are life satisfaction, domain satisfaction, and affective. This study found that efforts to maintain long-distance relationships are not easy, however it can be carried out with certain efforts such as maintaining harmony, mutual understanding, providing enough time, listening to their partner's complaints and always maintaining honesty between partners and family members.
\end{abstract}

Keywords: Well-Being, Couple; Long-Distance Relationship; Marriage

\begin{abstract}
ABSTRAK
Studi ini membahas tentang hubungan pernikahan jarak jauh antara pria atau wanita yang memiliki dua karier. Masing-masing memiliki hasrat untuk mempertahankan pernikahan namun di sisi lain memilih untuk mempertahankan karier sehingga pasangan tersebut harus mempunyai komitmen yang kuat. Studi ini dilakukan pada lima pasangan menikah yang memiliki hubungan jarak jauh. Kelima pasangan ini dipilih karena kemampuan mereka untuk menjaga rumah tangga mereka tetap harmonis bahkan dalam kondisi jarak jauh. Pendekatan psikologis diterapkan untuk mengujinya secara particuar dengan teori kesejahteraan subjektif. Kebahagiaan dalam konteks subjektif kesejahteraan adalah kepuasan hidup, kepuasan domain, dan afektif. Studi ini menemukan bahwa upaya untuk mempertahankan hubungan jarak jauh tidaklah mudah, namun dapat dilakukan dengan upaya tertentu seperti menjaga keselarasan, saling pengertian, menyediakan cukup waktu, mendengarkan keluhan pasangan mereka dan selalu menjaga kejujuran antara mereka dan anggota keluarga.
\end{abstract}

Kata Kunci: Kesejabteraan; Pasangan; Hubungan Jarak Jaub; Perkawinan

\section{PENDAHULUAN}

Kebahagian merupakan bentuk kesempurnaan (Williams: 2006) sebagai sesuatu yang sangat penting untuk diupayakan dalam sepanjang kehidupan manusia termasuk dalam perkawinan. Dalam liku-liku perjalanannya pemerolehan kebahagiaan dan kepuasan perkawinan akan berada pada sebuah proses yang berkorelasi dari faktorfaktor yang mengitarinya. Salah satu faktor penentu kebahagiaan (well being) seseorang 
di antaranya adalah keberfungsian seseorang dalam keluarga (Kelmer G., 2013; Botha, F.\& Booysen, F., 2014). Fungsi ideal semua anggota keluarga adalah mampu bereksplorasi dirinya dalam memberikan kasih sayang terhadap sesama anggota keluraganya.

Idealita sebuah keluarga adalah kelompok primer yang paling penting di dalam masyarakat (Ahmad, 1991), yang terbentuk dari hubungan antara laki-laki dan perempuan untuk menciptakan dan membesarkan anak-anak. George Murdock dalam Lestari (2013) secara mendalam menguraikan bahwa keluarga merupakan kelompok sosial yang memiliki karakteristik tinggal bersama, tempat kerjasama ekonomi, dan terjadinya proses reproduksi. Hal ini bermakna bahwa keluarga dalam bentuk yang murni merupakan satu kesatuan sosial yang terdiri dari suami, isteri dan anak-anak yang belum dewasa. Satuan ini mempunyai sifat-sifat tertentu yang sama, dimana saja dalam satuan masyarakat manusia.

Akhir-akhir ini fenomena perubahan dunia semakin tampak di kalangan masyarakat, yang ditandai adanya arus globalisasi yang cenderung merubah kebiasaan dan tingkah laku yang menjadikan ciri khas dari kehidupan manusia, termasuk keluarga. Tuntutan pekerjaan atau ekonomi yang semakin tinggi untuk biaya kehidupan berumah tangga memaksakan pasangan suami isteri berjauhan untuk memenuhi kebutuhan keluarganya. Pada hubungan suami-istri jarak jauh biasanya rentan akanterjadinya konflik.Beberapa kondisi dihadapi oleh suami-sitri jarak jauh, yaitu keterbatasanwaktu untuk bertemu, komunikasi yang tidak lancar, dan riskan terjadinya kesalahpahaman dan permasalahan lainnya. Walau demikian, ditemukan juga adanya fakta pada sebagian pasangan suami istri nampak tidak ada masalah dalam hubungan antara keduanya. Scott (2002) menyatakanbahwa hubungansuamiistri jarak jauh merupakan tipe yang cenderung tidak stabil, tidaksukses, bahkan cenderung bercerai (Stephen, 1990). Potensi konflik dari kondisi ini sangat besar. Permasalahan yang muncul misalnya rasa tidak percaya terhadappasangannya, kecemburuan, rasa rindu dan ingin segera bertemu sertapersoalan lainnya. Kondisi yang tidak tinggal serumah membuatindividu kurang memiliki waktu untuk melakukan interaksi secaralangsung setiap hari. Akibatnya, mereka belum mampu mengenalikebiasaan dan sifat pasangan yang sesungguhnya. Hal itu biasanya dapat diperoleh melalui interaksi yangintensif sebagaimana pasangan yang tinggal serumah 
(Rini, 2008). Jika suami-isteri dihadapkan dengan permasalahan karena adanya jarak dalam rumah tangga mereka, dapat dikatakan sebagai keluarga yang belum sejahtera secara psikologis.

Suami-isteri dikatakan memiliki kesejahteraan psikologis apabila ia merasa bahagia secara afektif dan puas dengan kehidupannya secara kognitif. Konsep keluarga bahagia pada kajian ini tidak ditekankan pada ketidakpunyaan dari sisi ekonomi yang dialami, namun bergantung pada bagaimana anggota keluarga mensikapi dan menyelesaikan masalah yang dihadapinya.Sennit (Balson, 1993) mengatakan bahwa keluarga yang memiliki banyak masalah, namun mengutamakan kebersamaan keluarga di atas segalanya dan tidak mudah terpengaruh dengan stimulus-stimulus di luar keluarga mereka, yang dikategorikan sebagai keluarga sehat atau harmonis.

Keluarga yang sehat adalah keluarga yang secara dasar beroperasi secara rasional, saling pengertian, bebas tekanan dan bebas dari konflik internal ekonomi (Hassan, et.al., 2012). Sementara suatu pendapat katakan bahwa keluarga bahagia atau keluarga harmonis adalah apabila seluruh anggota keluarga merasa bahagia ditandai oleh berkurangnya rasa ketegangan, kekecewaan dan mereka puas terhadap seluruh keadaan dan keberadaan dirinya, yang meliputi aspek fisik, mental, emosi dan sosial (Gunarsa, 1991). Gunarsa (1991) menyatakanbahwa keharmonisan keluarga dapat dilihat dalam beberapa bentuk, seperti melalui kasih sayang, saling menghargai dan menyayangi, saling pengertian dan terjalin komunikasi efektif antara suami isteri, dan lain-lain.Karenanya, permasalahan yang terjadi pada suami-isteri jarak jauh perlu dikaji lebih lanjut.

Kebahagiaan (happiness) dipahami secara berbeda dari beberapa ahli pengkajinya. Filsuf klasik G.W. Hegel berpandangan bahwa kebahagiaan pada dasarnya adalah konstruksi internal, bagian dari produk kognitif manusia. Karl Marx menyatakan bahwa kebahagiaan merupakan konsekuensi dari praktik kerja sosial, bersifat material dan historis (Freund, 1985). Dua pandangan ini bermakna bahwa pengukuran kebahagiaan manusia digunakan dua kategori variabel yaitu variabel mikro dan variabel sosial ekonomi (makro) (Casmini, 2018).

Pada konteks mikro, kebahagiaan bukan sekadar hasil dari emosi temporer ataupun bersifat jangka panjang, ataupun bukan produk kognitif dari cara berpikir 
rasional, melainkan sebuah konsekuensi dari proses interaksi antara struktur dan fungsi otak (Matsunaga, Kawamichi, Koike, dkk., 2016). Konsekuensi ini dipahami bahwa kebahagiaan dalam keluarga merupakan proses biologis yang melibatkan interaksi organ internal manusia. Termasuk menunjukkan bahwa sesuatu yang disebut psikis (psychological, jiwa) tidak dapat dipisahkan dari aspek fisik (physical). Dengan demikian terminologi kebahagiaan merupakan perwujudan fisik dan psikis seseorang.

Dalam konteks makro, kebahagiaan berhubungan langsung dengan aspekaspek sosial, ekonomi, teknologi dan politik (Lu Wei \& Fangfang, 2017). Eksplorasi mengenai kebahagiaan dalam sebuah keluarga akan memberikan kontribusi menarik jika dilakukan dengan melihat kaitan antara konteks-konteks eksternal (karakter geografis tempat keluarga hidup, kebijakan ekonomi-politik, dan perkembangan teknologi) dan konteks internal subjek (kesejahteraan psikologis).

Salah satu bentuk kebahagiaan adalah kesejahteraan subyektif atau subjective wellbeing yang disingkat dengan SWB (Diener. 2009; Snyder \& Lopez:,2007; Cheng \& Furnham, 2001; Casas, dkk., 2007; Ben-Zur, 2003) yang merupakan kebahagiaan yang menekankan pengalaman emosional yang menyenangkan atau sebagai evaluasi individu terhadap kesejahteraan psikologisnya, atau disebut happiness. Kebahagiaan dalam konteks subjective well-being memiliki dua unsur yaitu afektif dan kognitif (Diener dkk., 2003). Dalam dimensi afektif, kebahagiaan berada pada ranah perasaan bahagia dan secara kognitif merupakan penilaian terhadap hidupnya yang memuaskan. Unsur afektif berkenaan dengan emosi, suasana hati (mood) dan perasaan (feelings) individu tersebut,sedangkan unsur kognitif merujuk kepada pemikiran seorang individu terhadap kepuasan hidupnya secara menyeluruh dan juga secara spesifik atau dalam bagian-bagian tertentu, seperti kehidupan kerjanya atau hubungannya dengan individu yang lain (relation). Kebahagiaan merupakan salah satu kajian dalam psikologi positif, dan pendekatan teori yang ada salah satunya menggunakan teori need and goal satisfaction. Orang yang memiliki tujuan penting dan berjuang untuk meraihnya akan menjadi sosok yang lebih energik, mengalami banyak macam emosi positif dan akan merasa bahwa hidupnya sangat bermakna (McGregor \& Little, 1998).

Dari penelusuran kepustakaan yang telah dilakukan, diperoleh juga informasi bahwa beberapa peneliti telah melakukan kesimpulan bahwa kebahagiaanakan mengalami perubahan sesuai dengan kondisi kehidupan seseorang. Selain pendapat 
itu, teori selain need and goal satisfaction menyebutkan bahwa kestabilan karakter seseorang juga dapat mempengaruhi skor kebahagiaan.Adaptasi individu terhadap permasalahan-permasalahan dalam kehidupannya pun menjadi faktor penentu skor kebahagiaan pada tingkatan rendah atau tinggi.

Kebahagiaan dalam konteks subjective well-being memiliki tiga komponen yaitu kepuasan hidup (life satisfaction), kepuasan domain dan afektif (Diener et al., 2003; Schimach, 2008; Diener, Lucas \& Oishi, 2002) dan happiness, kemudian happiness terbagi secara dua yaitu afeksi positif dan negatif. Life satisfaction merupakan sisi kognitif dari SWB. Life satisfaction adalah suatu penilaian reflektif, suatu penilaian dalam diri seseorang, bagaimana sesuatu yang baik berjalan dan terjadi terhadap dirinya. Life Satisfaction dapat diungkap melalui kepuasan hidup secara global, maupun kepuasan domain-domain yang spesifik (Swinyard, Kau, \& Phua, 2000; Suldo \& Huebner, 2004; Diener, 2009; Brockmann \& Delhey, 2010). Asfek positif terdiri dari gambaran emosi dan suasana hati. Menurut Seligman (dalam Arieanti, 2011) emosi positif dapat dibedakan menjadi emosi positif akan masa lalu, masa sekarang, dan masa akan datang. Emosi positif mengenai masa depan mencakup optimisme, harapan, keyakinan dan kepercayaan. Emosi positif masa sekarang mencakup kegembiraan, ekstase, ketenangan, keriangan, semangat yang meluap-luap, dan flow. Emosi positif tentang masa lalu adalah kepuasan, kelegaan, kesuksesan, kebanggaan, dan kedamaian. Sementara asfek negatif di antaranya termasuk suasana hati dan emosi yang tidak menyenangkan. Diener (dalam Arieanti, 2011) menyebutkan bahwa emosi negatif yang paling sering dirasakan adalah kemarahan, kesedihan, kecemasan, kekhawatiran, stress, frustasi, merasa malu dan bersalah, serta iri hati. Seseorang dikatakan memiliki SWB tinggi apabila memenuhi kriteria, yaitu memiliki perasaan sangat bahagia, sangat puas dengan hidupnya, dan memiliki tingkat neurotisme yang rendah.

Individu yang sejahtera lebih banyak mengalami asfek positif dibandingkan aspek negatif dalam kehidupannya (Diener, 2009; Snyder \& Lopez, 2007; Seligman, 2005). Pasangan suami-istri yang memiliki kesejahteraan subyektif yang tinggi manakala lebih banyak mengalami perasaan senang, bahagia, dan puas dibandingkan dengan perasaan sedih, kecewa dan tidak bahagia. Hal ini menunjukkan bahwa suami-istri dengan SWB yang baik ditandai oleh dominasi asfek positif dan rendahnya 
asfek negatif pada dirinya. Suami-istri yang memiliki kesejahteraan subjektif yang baik,pada umumnya ia mampu melakukan penilaian subjektif terhadap kehidupannya secara keseluruhan.

Berdasarkan latar belakang di atas, yang akan menjadi focus bahasan pada tulisan ini adalah: (1) bagaimana dinamika kesejahteraan psikologis pada istri yang berada berjauhan? (apakah seorang isteri/suami, mampu menjaga komitmen dan menjaga keutuhan rumah tangganya di tengah-tengah keadaan dimana mereka ditinggalkan oleh suaminya?) dan (2) strategi manajemen kesejahteraan subyektif seperti apa yang dilakukan oleh isteri/suami untuk tetap menjaga keluarganya tetap harmoni?.

\section{METODE}

Penelitian ini menggunakan metode penelitian kualitatif, dengan data yang dihasilkan berupa kata-kata tertulis dari perilaku yang dapat diamati.Pendekatan ini diarahkan pada latar dari individu yang diamati secara holistik (utuh), dengan tidak mengalokasikan individu tetapi memandangnya sebagai satu kesatuan yang utuh.Jenis penelitian ini adalah penelitian lapangan dengan pendekatan fenomenologi, yaitu penelitian yang dilakukan dengan mengumpulkan data informasi pengalaman yang diperoleh langsung dari responden serta melakukan pengamatan terhadap kehidupan subyek.

Pengumpulan data dalam penelitian ini menggunakan metode wawancara mendalam yaitu suatu kegiatan yang dilakukan untuk mendapatkan informasi secara langsung pengalaman hidup sebagai LDR. Metode observasi digunakan untuk melihat perubahan subyektif well being saat berkumpul maupun saat ditinggalkan suami. Wawancara dilakukan terhadap lima subjek penelitian. Subjek pertama, Riza (24 tahun) yang merupakan seorang isteri yang berhubungan jarak jauh karena suami harus bekerja di Jepang (suaminya juga berasal dari Jepang). Subjek kedua bernama Hikmah (21 tahun). Ia adalah isteri yang mengalami hubungan jarak jauh karena faktor harus menyelesaikan pendidikannya di Yogyakarta sedangkan suami berada di daerah asalnya Jawa Barat untuk bekerja; Subjek ketiga adalah seorang istri yang mengalami hubungan jarak jauh karena tuntutan ekonomi yang mengharuskan suami bekerja di Bekasi. Subjek keempat adalah pasangan Atiatul dan Tobroni, dimana 
keluarga ini juga mengalami rumah tangga jarak jauh karena tuntutan ekonomi, dimana suami bekerja di Jakarta Pusat. Analisis data yang digunakan adalah menggunakan analisis isi (content analysis) dengan menggunakan teknik deskriptif naratif. Hasil wawancara diolah dan dianalisis berdasarkan tema yang ditemukan. Dengan kata lain, subjek dalam peneltian ini adalah 5 subjek dengan karakterisik keluarga yang mengalami long dinstance relationship. Berikut gambaran karakteristik subyek penelitian;

Tabel 1

Karakteristik Subyek Penelitian

\begin{tabular}{|l|l|l|l|c|}
\hline Nama/Usia & Usia Perkawinan & Lamanya LDR & Status LDR & $\begin{array}{c}\text { Jumlah } \\
\text { Anak }\end{array}$ \\
\hline $\begin{array}{l}\text { AL (22th) - HF } \\
\text { (24thn) }\end{array}$ & 3 tahun & 3 tahun & Pendidikan & 1 \\
\hline SL (41th) - SP (52th) & 22 tahun & 18 tahun & Ekonomi & 1 \\
\hline $\begin{array}{l}\text { SW (39th) - NA } \\
\text { (42th) }\end{array}$ & 21 tahun & 21 tahun & Ekonomi & 3 \\
\hline IM (30th) - HM (35th & 6 tahun & 3 tahun & Ekonomi & 1 \\
\hline SF (35th) - AN (36th) & 10 tahun & 1 tahun & Pendidikan & 2 \\
\hline
\end{tabular}

\section{HASIL DAN PEMBAHASAN}

Paparan hasil penelitian ini dilakukan dalam tiga tema narasi, yaitu kepuasan hidup (life satisfaction), afek positif (pleasant affect), dan afek negatif (unpleasant affect) sebagaimana dasar teori subjective well being. Tema kepuasan hidup memiliki empat sub tema yang didapatkan dari komponen kepuasan hidup, yaitu kepuasan saat berjauhan dan kepuasan ketika bertemu/berkumpul. Pada tema asfek positif dikelompokkan ke dalam tiga sub tema, yaitu sukacita, kebanggaan, kasih sayang dan tema asfek negatif pada tujuh sub tema, yaitu kesedihan, kekecewaan, iri hati, penyesalan, rasa malu, rasa marah, dan rasa bersalah. Subtema dari asfek positif dan asfek negatif didapatkan dari afeksi-afeksi yang yang dirasakan subjek pada pertanyaan yang diajukan selama proses wawancara dan observasi. Tiga tema temuan kesejahteraan subyektif dinarasikan dengan saling mendialogkan antara temuan kepuasan hidup (life satisfaction), afek positif (pleasant affect), dan afek negatif (unpleasant affect).

\section{Dinamika Kesejahteraan Subyektif Istri yang Suami Jarak Jauh}


Kepuasan hidup salah satunya ditentukan oleh faktor pengelolaan hubungan dalam rumah tangga dan keluarga yang meliputi kepuasan sosial, kepuasan eknomi dan kepuasan seksual. Kepuasan ini berimplikasi pada asfek positif dan negatif baik pada istri yang ditinggalkan dan suami yang meninggalkan. Dalam konteks kepuasan sosial, antara suami-istri berupaya untuk melakukan berbagai kegiatan untuk memenuhi kebutuhan hidup yang diinginkan. Status sosial ekonomi, dan fasilitas sosial mereka abaikan dalam menunjang kegiatan mereka, untuk melakukan tugas dan kewajibannya. Bagi suami-istri dikatakan memiliki kepuasan sosial ketika mereka memiliki kedekatan dengan orang lain, memiliki teman dan keluarga yang supportif cenderung puas akan seluruh kehidupannya. Sebaliknya, suami isteri dikatakan tidak memiliki kepuasan social apabila seperti kehilangan orang yang disayangi. Apabila itu terjadi, akan menyebabkan individu suami isterimenjadi tidak puas akan hidupnya. Akibatnya, individu tersebut memerlukan waktu untuk kembali menilai kehidupannya secara positif (Diener et al., 2009).

Deskripsi dinamika kesejahteraan subyektif dari kelima subyek dengan disparitas alasan yang bebeda dari masing-masing dalam memutuskan untuk hubungan jarak jauh. Dari kelima pasangan tersebut ada yang sejak awal memang memutuskan untuk hidup mandiri pisah dengan orang tua maupun mertua. Subyek IM misalnya ketika ditinggal suaminya untuk bekerja ke Taiwan, memutuskan untuk tinggal bersama orang tua dan anaknya yang masih berumur 1,5 tahun. Bermula dari ketidakpuasan dengan keluarga suami, IM secara psikologis selalu menahan perasaan, tertekan, imsomnia dan berbagai kegalauan yang dialami, hingga pernah mengalami depresi. Cerita IM pada awal ketika ditinggal suami sering mendapat perlakuan oleh Ibu mertuanya seperti dicaci dan dihina. "Duite okeh yooo anakku, gelem men kerjo adobadoh. yaa enak, bojone kerjo adoh koe nang kene iso dolan-dolan terus. Ngentekke duite bojomu, mentang-mentang okeh duite" Kata Ibu IM menirukan apa yang dibicarakan Ibu mertua kepadanya. Ketidakpuasan dengan keluarga suami, tertutupi dengan adanya dukungan teman-temannya IM yang anaknya sekolah bersama. Dukungan teman-temannya IM ini menjadikan dirinya merasa kuat dan tidak terlalu memikirkan omongan dari ibu mertuanya.

Perihal yang dialami IM dengan ibu mertuanya tidak diberitahukan kepada suami. Kekhawatiran akan menambah masalah dan mengganggu konsentrasi kerja 
membuat IM memilih tidak terbuka dengan perilaku ibu mertua kepada suaminya. Sedangkan suaminya bercerita ketika sampai di Taiwan justru dipertemukan dengan orang-orang baik. Rekan kerja dan atasannya sangat memahami kepada suaminya. Hal itu yang membuat suaminya semangat untuk tetap bekerja di luar negeri. Selain itu juga Bapak HM juga ingin membahagiakan isteri dengan memberikan rumah untuk tempat tinggal bersama anaknya, namun seringkali Bapak HM mempunyai kerinduan karena selama anaknya masih berumur 1,5 tahun hingga anaknya usia menginjak 5 tahun belum pernah ketemu lagi. Hal itu yang sering menjadi beban fikiran Bapak HM karena merasa bersalah tidak pernah memberikan kasih sayang secara langsung.

Berbeda dengan AL dengan HF dan SF dengan AN, dimana mereka menjalani LDR karena pendidikan. Kedua pasangan tersebut yang jauh dengan keluarganya dimana istri dari mereka masih menempuh pendidikan yang mengharuskan keduanya berjauhan, termasuk berjauhan dengan anak-anak mereka. Seperti AL dan HF, sebenarnya pasangan ini ketika memutuskan menikah selanjutnya ingin menunda memiliki momongan namun takdir berkata lain dimana Sang Maha Kuasa justru memberikan keturunan dengan cepat setelah satu bulan mereka menikah. Lalu mereka LDR mulai dari istrinya hami. Banyak yang dirasakan AL ketika masa hamil dengan kondisi yang jauh dengan suami dan keluarganya. AL sering mendapat perlakuan dari teman-temannya seperti banyak teman yang sebelumnya dekat ketika AL hamil justru menjauh. AL sering murung di Kamar dan ketika dalam kondisi apapun AL lakukan sendiri meskipun sampai sekarang juga teman-teman yang satu atap dengan AL masih seperti itu. Dengan kondisi itu, AL merasa diasingkan, termasuk ketika dia berbicara, dimana ia seringkali tidak direspon oleh temantemannya. Setelah AL melahirkan AL harus meninggalkan anaknya yang masih berumur 7 bulan kepada orang tuanya. AL merasa bahwa beliau tidak bisa memberikan kasih sayang sepenuhnya terhadap anaknya, apalagi melihat anaknya belum lancar berkomunikasi. Selanjutnya permasalahan yang dihadapi oleh HF karena berjauhan dengan pasangannya yang bekerja di luar kota, sementara ia memutuskan untuk tidak bekerja di luar kota semenjak anaknya lahir. Semenejak itu anaknya tinggal bersama suami dan ketika HF bekerja anaknya bersama bude HF. Selama menjalankan LDR HF banyak mendapatkan cemoohan dari tetangga karena 
dinilai sebagai suami yang menginginkan istrinya punya jabatan. Namun HF tidak pernah memikirkan hal itu karena hal ini dilakukan karena HF karena HF ingin istrinya menjadi ibu yang cerdas untuk anak-anaknya.

Sedangkan pasangan SF dan AN, SF pergi ke Jogja untuk melanjutkan studinya, dengan memutuskan untuk LDR SF meninggalkan 2 anak bersama suaminya di Ciamis. SF dan AN sangat menikmati LDR ini karena orang-orang yang ada disekitar mereka sangat memberikan support kepada SF dan AN mauun kepada kedua anaknya. Anak-anaknya juga memahami betul alasan ibunya pergi. Selanjutnya hasil wawancara dengan SL-SP dan SW-NA ada kesamaan antara kedua pasangan tersebut, dimana mereka tinggal di rumah sendiri meskipun keduanya tinggal di rumah kontrakan dekat orang tuanya, dan keduanya juga mendapatkan dukungan dari orang-orang sekitar seperti pasangan sebelumnya SF dan AN.

Dari beberapa kasus di atas, dapat dikatakan bahwa IM kurang mendapatkan kepuasan sosial karena kurang baiknya hubungan dengan orang tua, meskipun sekarang IM sudah bisa mengatasinya karena dukungan teman-temannya. Berbeda dengan keadaan yang dirasakan suaminya, suaminya cukup merasakan kepuasan sosial karena sikap positif orang-orang yang berada disekitarnya. Sedangkan AL juga merasakan hal yang sama yaitu kurangnya dukungan orang-orang sekitar sehingga membuat dirinya diluputi perasaan sedih dan suka murung di kamar. Sama halnya juga dengan suami AL yaitu HF yang juga seringkali dijadikan bahan pembicaraan dilingkungan rumahnya karena membiarkan istrinya meninggalkan anaknya yang masih kecil. Namun ada juga pasangan yang merasakan dirinya menikmati LDR ini karena dukungan dari orang-orang sekitarnya seperti pasangan SL-SP, SW-NA, dan SF-AN.

Selain hubungan dengan orang sekitar, disini peneliti juga menanyakan seputar komunikasi yang terjalin diantara mereka dengan pasangannya. Berdasarkan hasil wawancara dan observasi kepada beberapa responden yang merekapun menjalani hubungan jarak jauh dalam rumah tangganya. Hal tersebut menjadikan intensitas pertemuan yang terbatas yaitusebulan sekali atau jika urusan sudah selesai, ada waktu luang diusahakan untuk pulang. Dari kondisi seperti itu pasangan ini memaksimalkan komunikasinya pada media telepon, sms, dan videocall agar terjalin komunikasi yang baik dalam rumah tangganya karena mereka percaya bahwa komunikasi adalah hal 
yang penting dalam menjalin suatu hubungan. Tidak dipungkiri konflik dalam rumah tangga merupakan suatu hal yang lazim dan pasti terjadi. Misalnya kesalahpahaman ketika suami menelepon, sementara istri tidak menjawab karena suatu pekerjaan namun mereka mampu mengatasinya dengan menjelaskan alasannya dan saling pengertian sehingga mereka masih tetap mampu menjaga keutuhan keluarganya dan keharmonisannya. Dalam menjaga komunikasi agar tetap berjalan dengan baik beberapa responden memilih untuk melakukan beberapa hal untuk dapat menjalin hubungan tetap dekat meskipun jarak yang memisahkan. Hal tersebut antara lain; tetap menjaga komunikasi meskipun sebentar, saling memberi kabar jika akan melakukan kesibukan supaya tidak salah paham atau saling curiga. Ada beberapa hal yang perlu diperhatikan oleh pasangan suami isteri yang berjauhan, seperti kepuasan ekonomi, kepuasan seksual, saling pengertian sesama anggota keluarga, dan lain-lain.

Selanjutnya yang perlu diperhatikan adalah kepuasan ekonomi. Kepuasan Ekonomi adalah perasaan senang atau kenikmatan yang dialami seseorang dalam memenuhi kebutuhan sehari-harinya dengan baik sehingga orang tersebut mendapatkan barang yang dia inginkan. Dari kelima responden tersebut beragam jawaban yang diterima peneliti, seperti IM-HM. IM mengaku jika sebelum suaminya HM bekerja di luar negeri beliau mengalami kesulitan ekonomi, IM tidak bisa membeli barang yang dia inginkan karena untuk memenuhi kebutuhan sehari-harinya juga gali lubang tutup lubang dan hal ini sering menimbulkan pertengkaran diantara mereka karena mereka merasakan kebingungan ketika harus melanjutkan hidup dengan keadaan yang seperti itu. Namun ketika suaminya bekerja di luar negeri IM dan anaknya bisa membeli barang yang mereka inginkan meskipun demikian IM tidak hanya mengandalkan gaji suaminya selain IM menjadi ibu rumah tangga IM juga buka usaha catering. Modal itu didapat juga dari hasil tabungan ketika diberikan uang oleh suaminya. Begitu juga suaminya HM, HM merasakan kebahagiaan seorang suami karena bisa memberikan nafkah sehingga istrinya dapat membuka usaha dan juga dapat membahagiakan anaknya sehingga anaknya dapat seperti anak yang lainnya. Semua gaji yang diterima suami sebagian diberikan kepada istri sebagian lagi suami simpan untuk kebutuhan hidupnya sehari-hari. Meskipun pada awal pemberangkatannya IM-HM harus bejalan dari bank satu ke bank yang lainnya. 
Sekarang HM bersyukur karena semuanya sudah diselesaikan. Meskipun demikian IM harus bisa mengatur keuangannya untuk mewujudkan impiannya yang belum terwujud.

Sedangkan AL-HF sedikit bermasalah karena keuangan karena HF sendiri ketika memutuskan istrinya untuk melanjutkan studinya dia harus resend dari pekerjaan yang dahulu karena dia ingin agar anaknya bersama dengan salah satu orang tuanya. Dari hal itu ketika mereka memutuskan LDR HF tidak ada pemasukan yang tetap, HF hanya mengandalkan tabungan saja. Namun ketika 6 bulan LDR HF memutuskan untuk membuka usaha bersama kakaknya dan akhirnya ekonomi HF kembali membaik. Ketika hasil usahanya diterima suami hanya memberiistrinya 30\% sesuai kesepakatan. Hal itu dilakukan karena anaknya bersama suami. Walau demikian AL dapat mengatur uang dengan baik misalnya ketika ia diberikan suaminya AL selalu menyisihkannya untuk menabung. AL juga masih bisa memenuhi kebutuhan pokoknya maupun kebutuhan-kebutuhan lainnya. Selain AL kuliah, AL juga tidak berdiam diri sebagai mahasiswa namun Al juga membuka usaha jilbab yang digelutinya bersama temannya. Hasil dari jualannya disisihkan AL untuk menabung.

Lain halnya dengan SP, ia selalu memberikan nafkah setiap sebulan sekali kepada pasangannya, dimana gaji yang ia diperoleh semuanya diserahkan kepada istrinya. Dirinya dalam memenuhi kebutuhannya mengandalkan bonus dari kerjanya. Gaji yang diterima istri SP juga harus diperuntukkan juga buat mertuanya karena SP masih mempunyai tanggungan adik yang masih sekolah. Dari kondisi itu tidak memicu masalah yang berarti karena disisi lain SL sebagai istrinya juga membuka usaha toko sembako di rumahnya. Hal ini sama seperti pasangan SW-NA. Selain suaminya bekerja di luar kota SW juga membuka usaha warung sembako di rumahnya. Walaupun demikian, gaji yang diperoleh suaminya tidak menetap dikarenakan tidak selalu ada proyek ataupun pekerjaan yang membutuhkan tenaga suaminya. Dari kondisi itu SW justru harus lebih bisa mengatur keuangan untuk masa depan anaknya. Ketika suami sedang tidak ada, subjek ini merasakan pekerjaannya seringkali menimbulkan masalah karena pemasukan tidak sebanding dengan pengeluaran. Walau demikian, subjek ini dalam menghadapi masalahnya tersebut segera diselesaikan karena biasanya suaminya juga tidak mengandalkan pekerjaannya sebagai tukang kayu. Ketika sedang sepi, suaminya mau bekerja serabutan. 
Sedangkan SF dan AN, dalam memenuhi kebutuhannya sangat mudah karena mengingat AN bekerja sebagai dosen dan SF juga bekerja sebagai dosen. SF justru kehidupannya cenderung hedonis. Meskipun sedang berada jauh dari suaminya seringkali SF pergi belanja bersama teman-temannya. Namun suaminya tidak pernah mempermasalahkan asal SF melakukan hal yang positif, walaupun masing-masing dari mereka mempunyai pendapatan masing-masing AN sebagai suami tetap memberikan nafkah kepada SF, nafkah yang diberikan cenderung untuk kebutuhan anak-anaknya dan selama SF melanjutkan studinya di luar kota, dan pendapatan SF sendiri untuk ditabung untuk bekal masa depan. Namun diakui AN semenjak LDR dengan istrinya pengeluaran lebih banyak dibandingkan tidak LDR, karena banyak mengeluarkan biaya untuk transportasi karena sering mengunjungi istrinya ataupun istrinya pulang ke rumah.

Dari hasil wawancara tersebut pada dasarnya rumah tangga akan harmonis ketika dalam rumah tangganya kebutuhan dapat terpenuhi. Ketika ada masalah mengenai ekonomi juga dapat mempengaruhi hubungan suami istri. Karena biasanya harga diri seorang suami terletak ketika suami itu sendiri dapat memenuhi kebutuhan istri dan anaknya. Ketika keadaan ekonominya baik tentunya akan menciptakan suasana yang bahagia karena apa yang dibutuhkan dapat dipenuhi meskipun demikian kebahagiaan tidak hanya diukur dengan materi, namun materi juga penting dalam menunjang kehidupan suami-istri.

Dalam berkeluarga, suami isteri juga perlu memperhatikan kepuasan seksual. Kepuasan seksual merupakan suatu bentuk perasaan yang dirasakan oleh pasangan atas kualitas hubungan seksual mereka yang dapat berupa sentuhan fisik dan psikis. Kepuasan seksual adalah salah satu kunci kehamonisan dalam rumah tangga setiap orang membutuhkan kepuasan seksual dan masing-masing memiliki standart bagaimana ia mendapatkan kepuasan seksual. Untuk itu, baik adanya jika pasangan saling mengetahui apa arti kepuasan seksual agar pasangan dapat saling memberikan kepuasan seksual dan salah satu atau kedua belah pihak tidak saling meningalkan, bahkan berujung pada perselingkuhan.

Berdasarkan hasil wawancara dengan kelima pasangan, mereka tidak menjawabnya secara terbuka mengenai kepuasan seksual ini. Seperti SL-SP mengaku tidak ada sikap atau emosi yang menunjukkan pasangan menginginkan hubungan 
seksual, karena bagi mereka hubungan seksual hanya sebagai penyedap dalam rumah tangga bukan hal yang prioritas dan juga mengingat usia yang tidak lagi muda, saling mengerti saja antara satu sama lain, ingat tujuan awal jadi mereka dapat menahan meskipun mungkin terkadang ketika dalam puncaknya suami mendadak sering menghubungi apalagi seperti SL-SP yang ketemunya 2-3 tahun sekali. Mereka tidak memberi tahu bagaimana cara mereka menyalurkan keinginan seksual mereka.

Sedangkan AL-HF, terutama HF sebagai suami sering tidak bisa mengontrol emosi ketika keinginan untuk berhubungan seksual tidak tersalurkan mendadak cari perhatian. AL sebagai istri biasanya yang dia lakukan sabar, memberikan pengertian, dan terkadang juga langsung pulang jika suaminya sudah tidak bisa dikendalikan. Suaminya dalam menyalurkan keinginan seksualnya biasanya dengan melihat foto istri HF sudah merasakan kepuasan tak jarang pula meminta istri untuk foto seksi. AL cenderung tidak pernah mempunyai keinginan seksual yang menggebu Al lebih bisa menahan dan mengaturnya. Berbeda dengan SF-AN mereka selalu tersalurkan keinginan hubungan seksualnya karena mereka pasti bertemu satu minggu sekali terkadang suami yang ke tempat istri dan sebaliknya.

Hasil wawancara pasangan IM-HM, antara keduanya tidak pernah ada masalah karena kepuasan seksual karena masing-masing jujur ketika menginginkan hal tersebut dan saling terbuka, saling menanggapi satu sama lain. Dan biasanya mereka menyalurkannya dengan video call. Sedangkan pasangan SW-NA hampir sama dengan apa yang dilakukan SL-SP mereka tidak pernah mempermasalahkan mengenai kepuasan mereka dalam seksual karena mereka berfikir usia mereka yang tidak lagi muda. SL-SP menyalurkannya hanya ketika mereka bertemu. Dalam sehari-hari yang banyak dibicarakan hanya keadaan anak-anaknya.

Dari kelima responden tersebut dapat diambil kesimpulan jika suami lebih dominan menginginkan hubungan seksual meskipun jarak mereka jauh.Ketika hal itu tidak tersalurkan suami gampang emosi dan cenderung tidak bisa menahannya. Maka dari itu ketika hubungan seksual tidak tersalurkan dengan baik banyak dampak yang akan timbul. Misalnya ketika istri tidak dapat memenuhinya kebutuhan suaminya, suami akan menyalurkannya kepada wanita lain. Kondisi itu tentu saja mengakibatkan terjadinya perselingkuhan. Artinya dapat dikatakan bahwa kebahagiaan dalam suatu rumah tangga akan baik jika antar pasangan dapat menyalurkan keinginan biologisnya 
dengan baik. Namun demikian hal ini bukan tolak ukur yang dominan dalam suatu kebahagiaan dalam rumah tangga karena tidak tertutup kemungkinan akan adanya faktor-faktor lain sebagai penyebabnya, seperti dua kepuasan yang dibahas sebelumnya.

\section{Strategi Manajemen Kesejahteraan Subyektif Istri yang Suami Jarak Jauh}

Ada beberapa langkah yang dapat ditempuh untuk mengatasi permasalah yang dihadapi suami-isteri yang berjauhan/LDR:.

\section{Kasih sayang antar anggota keluarga}

Ungkapan Smith (2005) bahwa miskinnya komunikasi akan menyebabkan terjadinya ketidakseimbangandi dalam keluarga karena keluarga yang seimbang ditunjukkan dengan adanya keterbukaan di dalam berkomunikasi. Pasangan tidak terbuka maka akan sulit bagi satu sama lain untuk berbagi informasi sebanyakbanyaknya dalam waktu yang terbatas tersebut (Scott, 2002). Dalam perkawinan, ada empat hal yang menjadi tugas perkawinan bagisepasang suami istri agar dapat menjaga keintiman dan keharmonisan keluarga, yaitu (1) pembagian tanggung jawab di dalam kehidupan rumah tangga, (2) komunikasi, (3) seks dalam perkawinan, dan (4) penerimaan akan perubahan yang terjadi pada pasangan sepanjang waktu di dalam kehidupan perkawinan (Bachrad, Hindin \& Thompson, dalam Elfida, 2011). Anggota keluarga menunjukkan saling menghargai dan saling menyayangi, mereka bisa merasakan betapa baiknya keluarga. Anggota keluarga mengekspresikan penghargaan dan kasih sayang secara jujur. Penghargaan itu mutlak diperlukan, karena dengan demikian masing-masing anggota merasa sangat dicintai dan diakui keberadaannya.

Berdasarkan hasil yang diperoleh pada hasil wawancara dan observasi terungkap bahwa keempat subjek yang mengalami rumah tangga jarak jauh, hubungan emosional dengan pasangan berjalan dengan baik dan harmonis. Kasih sayang dan rasa cinta yang menguatkan keluarga mereka. Namun salah satu subjek, yaitu subjek pertama memaparkan hubungan emosional dengan anggota keluarga yaitu anak kurang baik karena keterbatasan bahasa karena suami berasal dari luar negeri dan juga kurang dekatnya dengan anak yang selayaknya hubungan ayah dan anak intens untuk bertemu dan berkomunikasi.

Saling pengertian sesama anggota keluarga 
Selain kasih sayang, pada umumnya pasangan suami-isteri mengharapkan adanya pengertian antar keduanya maupun dengan anggota keluarganya. Dengan adanya saling pengertian maka tidak akan terjadi pertengkaran-pertengkaran antar sesama anggota keluarga. Berdasarkan hasil wawancara dan observasi dari keempat subjek terungkap bahwa antar suami dan istri saling memahami dan mengerti akan kondisi yang sedang terjadi, mereka beranggapan saling pengertian akan memperkuat hubungan mereka karena hal itu sangat penting. Dari subjek pertama dan kedua, saling pengertian itu penting karena itu sudah menjadi komitmen dari awal pernikahan mereka.

\section{Dialog atau komunikasi efektif yang terjalin di dalam keluarga}

Berdasarkan hasil wawancara dan observasi kepada beberapa responden yang merekapun menjalani hubungan jarak jauh dalam rumah tangganya. Hal tersebut menjadikan intensitas pertemuan yang terbatas yaitu tiga bulan sekali. Akibatnya, pasangan ini memaksimalkan komunikasinya pada media telepon dan sms agar terjalin komunikasi yang baik dalam rumah tangganya karena mereka percaya bahwa komunikasi adalah hal yang penting dalam menjalin suatu hubungan. Tidak dipungkiri konflik dalam rumah tangga merupakan suatu hal yang lazim dan pasti terjadi misalnya kesalahpahaman ketika suami menelepon, sementara istri tidak menjawab karena suatu pekerjaan namun mereka mampu mengatasinya dengan menjelaskan alasannya dan saling pengertian sehingga mereka masih tetap mampu menjaga keutuhan keluarganya dan keharmonisannya. Dalam menjaga komunikasi agar tetap berjalan dengan baik beberapa responden memilih untuk melakukan beberapa hal unruk dapat menjalin hubungan tetap dekat meskipun jarak yang memisahkan, hal tersebut antara lain.

\section{Menyediakan cukup waktu}

Beberapa responden mengatakan bahwa sesibuk apapun pekerjaan yang dialami oleh pasangannya (suami) tetap menghubungi keluarganya di rumah. Misalkan kegiatan yang wajib dilakukan oleh Tobroni (37 tahun) selalu menelpon keluarganya yang berada di rumah yaitu isteri dan seorang anak laki-lakinya yang masih bersekolah di Taman Kanak-kanak. Seusai istirahat makan siang dia selalu menanyakan kepada isteri dan anaknya sedang apa, dimana dan sudah makan belum. Itu salah satu bukti bahwa suami tetap menyediakan cukup waktunya untuk 
keluarganya yang berada jauh di rumah.Untuk subjek pertama, pasangan ini cukup baik memanfaatkan waktu luang mereka jika ada sela-sela istirahat suami sering telpon atau video call dengan anaknya.

\section{Mendengarkan pasangannya}

Dari hasil wawancara beberapa responden tentang komunikasi di dalam keluarga didapatkan bahwa selain menyediakan waktu yang cukup untuk keluarganya setiap pasangan juga seharusnya saling pengertian dengan menjadi pendengar yang aktif bagi pasangannya dan memberikan feedback yang dapat memberikan pasangannya merasa nyaman.Jika dikaitkan dengan hasil wawancara, Robingah (47 tahun) memberikan pemaparan bahwa meskipun saat ini dia sedang berada jauh dari suaminya, tak lantas dia merasa kesepian dan merasa tidak tenang tinggal di rumahnya bersama anak-anaknya. Dia mengakui saat mengalami banyak pikiran tentang masalah ekonomi, hubungan dengan tetangga dan masalah yang lainnya dia selalu menceritakan kepada suaminya yang berada di Bekasi Jawa Barat, begitupun dengan suaminya. Zani (49 tahun) selalu mendengarkan keluh kesah isterinya itu dan memberikan ketenangan dngan memecahkan masalah yang sedang dihadapi sebagai solusi. Riza (24 tahun) dengan suaminya selalu menjaga komunikasi dengan saling mendengarkan segala macam keluh kesah dan keadaan apapun soal anak.

\section{Mempertahankan kejujuran}

Kejujuran merupakan salah satu kunci menjaga komitmen ikatan pernikahan dan keutuhan rumah tangga. Dengan adanya keterbukaan antar pasangan menjadikan sebuah keharmonisan di dalam keluarga tidak ada sesuatu yang disembunyikan satu dengan yang lainnya. At (32 tahun) mengakui bahwa yang menjadikan langgeng di keluarganya adalah kejujuran pasangannya, yaitu (To) suaminya yang berada di Jakarta Pusat ini selalu menjaga komitmennya sebagai suaminya. At mengatakan suaminya itu merupakan suami idaman yang selalu menjaga kesetiannya. Suaminya selalu memberitahu jika akan pergi kemana, dengan siapa dan acara apa, begitu juga sebaliknya. Sebagai isteri, At selalu memberitahu kepada suaminya tentang apa dan hendak dilakukannya. Subjek pertama juga dari awal pernikahan berkomitmen untuk selalu jujur dengan pasangan walau apapun yang terjadi.

\section{Mempunyai waktu bersama dan kerjasama dalam keluarga}


Keluarga menghabiskan waktu (kualitas dan kuantitas waktu yang besar) diantara mereka. Kebersamaan di antara mereka sangatlah kuat, namun tidak mengekang. Selain itu, kerjasama yang baik antara sesama anggota keluarga juga sangat dibutuhkan dalam kehidupan sehari-hari. Adanya saling membantu dan gotong royong dalam keluarga akan mendorong suami isteri dan anak untuk bersifat toleransi, jika kelakbersosialisasi dalam masyarakat.

Berdasarkan hasil wawancara dan observasi terungkap bahwa keempat subjek cukup baik untuk bisa meluangkan waktu bersama keluarga dan juga tentang kerjasama dalam keluarga mereka. Dari subjek pertama, jika suami pulang ke Indonesia dia memanfaatkan waktunya yang singkat dengan quality time bersama anak dan isterinya, namun subjek memaparkan bahwa quality time nya itu diatur dengan baik, yaitu hari pertama saat suami pulang digunakan untuk anaknya, dan hari selanjutnya untuk istrinya. Tentang kerjasama terutama pengasuhan anak mereka, suami menyerahkan sepenuhnya ke istri karena ia tidak bisa langsung mematau anaknya setiap hari.

\section{SIMPULAN}

Keharmonisan dalam keluarga merupakan hal yang selalu diidam-idamkan oleh setiap pasanganyang sudah menikah. Bahkan setiap pasangan selalu berusaha menciptakan keharmonisan antar pasangannya meciptakan keluarga yang tentram dan bahagia. Keharmonisan dalam keluarga merupakan suatu situasi atau kondisi keluarga dimana terjalinnya kasih sayang, saling pengertian, dukungan, mempunyai waktu bersama keluarga, adanya kerjasama dalam keluarga, komunikasi dan setiap anggota keluarga dapat mengaktualisasikan diri dengan baik serta minimnya konflik, ketegangan dan kekecewaan.

Kehidupan dalam pernikahan dapat dilakukan dengan dua cara yakni pernikahan jarak jauh (long distance marriage/commuter marriage) ataupun tinggal dalam satu rumah (proximal marriage). Karena berbagai alasan seperti faktor ekonomi, karir, ataupun pendidikan tidak jarang pasangan suami istri mengambil keputusan untuk menjalani pernikahan jarak jauh. Pernikahan jarak jauh adalah pria atau wanita dalam pernikahan yang mempunyai dua karir, dimana masing-masing memiliki keinginan 
untuk mempertahankan pernikahan namun secara sukarela juga memilih untuk menjaga karir sehingga pasangan tersebut merasakan adanya komitmen yang kuat.

Lima pasangan yang dijadikan informan mampu menjaga rumah tangganya tetap harmonis meski dalam keadaan jarak jauh. Untuk mengatasi permasalahan suami isteri jarak jauh agar tidak menjadi masalah, perlu adanya kerjasama antar pasangan yang sudah berjanji dan berkomitmen untuk menikah dan menjaga pasangannya. Selain itu, perlu adanya usaha yang dapat dilakukan oleh kedua pasangan dalam menjaga keharmonisan keluarganya, seperti, saling mengasihi dan menyayangi anggota keluarga, saling pengertian antara sesama anggota keluarga, menyediakan cukup waktu untuk pasangannya, mendengarkan keluh kesah pasangannya dan selalu menjaga kejujuran antar pasangan dan anggota keluarga. Dengan begitu, keluarga sakinah yang diinginkan dapat diwujudkan. Dari semua responden yang diobservasi dan wawancarai dari beberapa aspek dimana keluarga tersebut dapat dikatakan keluarga yang harmonis, walau kadang terjadi konflik namun tidak menjadikan masalah besar bagi keluarganya.

\section{DAFTAR PUSTAKA}

Argyle, M., The Psychology of Happiness2nd ed., USA: Routledge, 2001

Arikunto, Suharsimi, Prosedur Penelitian Suatu Pendekatan Praktik, Jakarta: PT. Beall, C. 2011

Beall, C., Healing Your Marriage When Trust Is Broken. New York, NY: Harvest House Publizer, 2011

Botha, F. \& Booysen, F. 2014, Family Functioning and Life Satisfaction and Happiness in South African Households, Social Indicators Research.119 (1), pp 163-182,https://doi.org/10.1007/s11205-013-0485-6

Crossley, Adam \& Langdridge, Darren, Perceived Sources of Happiness: a Network Analysis. Journal of Happiness Studies. 6, 2005

Dewi, N., Commuter Marriage, Bogor: IPB Press, 2010

Sharp, R., Living Trust For Everyone, New York, NY: All Worth Press, 2013

Diener, Ed \& Ryan, Katherine, Subjective Well Being: a General Overview. South African Journal of Psychology. Vol 39 (4), 2009

Elfida, D., Penyesuaian perkawinan ditinjau dari beberapa faktor demografi. Jurnal Psikologi, 7(2), 2011 
Gunarsa, Singgih D dan Yulia Singgih D. Gunarsa, Psikologi Praktis Anak dan Keluarga, Jakarta: Gunung Mulia, 1991.

Kelmer G., Rhoades, G.K., Stanley, C., \& Markman, H.J., 2013. Relationship Quality, Commitment, and Stability in Long-Distance Relationships, Family Process. 52 (2), 155-350. https://doi.org/10.1111/j.1545-5300.2012.01418.x

Lestari, Sri, Psikologi Keluarga Penanaman Nilai dan Penanganan Konflik dalam Keluarga, Jakarta: Prenanda Media Grup, 2013

P. Joko Subagyo, Metode Penelitian dalam Teori dan Praktek, Jakarta: Rineka Cipta, 2006

Ryff, C., Happiness is everything, or is it? Explorations on the meaning ofpsychological well being.Journal of Personality and SocialPsychology.57 (6), 1989

Shenkman, M., The Completed Book of Trusts (3rd ed). New York, NY: John Wiley \& Sons., 2004

Tessina, T., The Commuter Marriage, Fort Collins, co.: Adams Media, 2008

Williams, K, Brian; Sawyer, C, Stacey \& Wahlstrom, M, Carl., Marriages, Families \& Intimate Relationship. A Practical Introduction. USA: Pearson Education, Inc., 2006 